\title{
Meghatározza-e az oldaliság az irreszekábilis metasztatikus colorectalis carcinoma első vonalbeli kezelését?
}

\author{
Kullmann Tamás dr. - Sipőcz István dr. - Pintér Tamás dr. \\ Petz Aladár Megyei Oktató Kórház, Onkoradiológiai Osztály, Győr
}

\begin{abstract}
Bevezetés és céllitüzés: A nem reszekábilis metasztatikus vastagbéldaganatok várható medián túlélése elérheti a három évet. A kezelési stratégiában nem tisztázott a célzott kezelések optimális alkalmazási szekvenciája. Klinikai vizsgálatok retrospektív analízise alapján felvetették, hogy a bal oldali vastagbéldaganatok első vonalbeli kezelésében az EGFRgátló cetuximab, illetve panitumumab hatékonyabbak volnának a VEGF-gátló bevacizumabhoz képest. Módszer: Közleményünkben rámutatunk az elemzések hiányosságaira: a kontrollcsoportok közötti egyenlótlenségre, az első vonalat követő kezelések figyelmen kívül hagyására, a progressziómentes és a teljes túlélési előny közötti ellentmondásra, illetve a kizárt betegek magas arányára. Eredmények: A vizsgálatok egyértelmúen megerösítik, hogy a jobb oldali vastagbéldaganatok prognózisa a bal oldali daganatokhoz képest rosszabb. Következtetés: Véleményünk szerint jelenleg még nem áll rendelkezésünkre elegendő adat az első vonalbeli célzott kezelés megválasztására RAS és BRAF vad típusú áttétes bal oldali vastagbéldaganat terápiájában. Több vizsgálat retrospektív analízise arra utal viszont, hogy a jobb oldali vastagbéldaganatok kezelésében az EGFR-gátló kezelésnek a kemoterápiához képest hozzáadott előnye nincs. Orv. Hetil., 2017, 158(9), 340-344.
\end{abstract}

Kulcsszavak: áttétes vastagbéldaganat, bevacizumab, cetuximab, panitumumab, kemoterápia

\section{Does the sidedness determine the first line treatment of irresectable metastatic colorectal cancer?}

Introduction and aim: Median life expectancy of non-resectable metastatic colorectal cancer may surpass three years. However, several points of the treatment strategy are subject of ongoing debate. Optimal sequence of targeted agents is not elucidated either. Based on retrospective analyses of six clinical studies and a metaanalysis, the superiority of anti-EGFR agents such as cetuximab and panitumumab over anti-VEGF bevacizumab has been proposed in the treatment of left sided tumours. Method: The results of the six major clinical trials were analysed. Insufficiencies of the meta-analysis are pointed: the lack of homogeneity among control groups, the omission of later lines of therapy, the inconsistency between progression free and overall survival benefit and the high proportion of excluded patients. Results: The trials confirm the worse prognosis of right sided versus left sided colorectal cancers. Conclusion: To date the data are not strong enough to support the preference of any of the available targeted agents at the first line setting in the treatment of left sided metastatic RAS and BRAF wild type colorectal cancers. Several trials suggest that antiEGFR treatment has no additional benefit as compared to chemotherapy alone in the treatment of right-sided tumours.

Keywords: metastatic colorectal cancer, bevacizumab, cetuximab, panitumumab, chemotherapy

Kullmann, T., Sipöcz, I., Pintér, T. [Does the sidedness determine the first line treatment of irresectable metastatic colorectal cancer?]. Orv. Hetil., 2017, 158(9), 340-344.

(Beérkezett: 2016. december 4.; elfogadva: 2017. január 16.) 


\section{Rövidítések}

BRAF = B-Raf fehérje termelődéséért felelős onkogén; CALGB = Cancer and Leukemia Group B (a szervezet nevén futó 80405 . számú klinikai vizsgálat referenciájaként is használatos rövidítés); COIN = klinikai vizsgálat; $\mathrm{EGFR}=$ epidermal growth factor; ESMO = European Society for Medical Oncology; FIRE3 = klinikai vizsgálat; FOLFIRI = 5-fluorouracil, kalcium-folinát, irinotecan (kombinált kemoterápiás protokoll); FOLFOX = 5-fluorouracil, kalcium-folinát, oxaliplatin (kombinált kemoterápiás protokoll); RAS = Ras fehérje termelődéséért felelős onkogén; VEGF = vascular endothelial growth factor

\section{Történelmi vázlat}

A sebészeti technika, a kemoterápiás és a célzott kezelések fejlődésének, illetve a sebész-onkológus együttmúködés javulásának köszönhetően az áttétes vastagbéldaganatok egy része feltételesen gyógyítható betegséggé vált. A többséget képezô nem gyógyítható betegek várható medián túlélése három évtized alatt háromszorosára nőtt, és manapság eléri a három évet.

Az 1980-as években az akkor egyedül hatásosnak ismert kemoterápia, az 5 -fluorouracil és kalcium-folinát kombináció kedvező adagolási sémája állt a kutatások középpontjában. Kidolgozták a Mayo- [1] és a de Gramont- [2] protokollt. Az 1990-es években egészült ki a kezelés az oxaliplatinnal, illetve az irinotecannal, és születtek meg a FOLFOX- [3] és a FOLFIRI- [4] protokollok. A két kemoterápiás protokoll szekvenciális alkalmazását is összehasonlították, és nem találtak szignifikáns válaszadási, illetve túlélési különbséget az alkalmazási sorrend függvényében [5].

A 2000-es években jelentek meg a célzott kezelések, a VEGF-gátló bevacizumab [6] és az EGFR-gátló cetuximab [7], valamint panitumumab [8]. Mindkét típusú célzott kezelés FOLFOX- vagy FOLFIRI-kemoterápia mellett adva növeli a progressziómentes túlélést. A VEGF-gátló kezelésnek nincs prediktív markere. EGFRgátló kezelés alkalmazásától csak vad típusú RAS- és BRAF-státuszú daganat esetén várható klinikai elóny. Vad státuszú daganatok esetén mindkét fajta célzott kezelés alkalmazható. A két különböző támadáspontú célzott kezelést csak kevés kontrollált vizsgálat hasonlította össze és eredményeik ellentmondásosak. A közelmúltig a két kezelést lényegében egyenértékünek tartották, és szekvenciális alkalmazásukra nem volt egyértelmű ajánlás.

A 2010-es években ezenkívül az Egyesült Államokban törzskönyvi engedélyt kapott a regorafenib, a ramucirumab, a trifluridin/tipiracil és a zivaflibercept [9], ám ezek a szerek Magyarországon vagy nem terjedtek el széles körben, vagy nem kaptak még forgalomba hozatali engedélyt.

Klinikai vizsgálatok retrospektív analízise alapján újabban felvetették, hogy a bal oldali vastagbéldaganatok első vonalbeli kezelésében kemoterápiával kombinálva az EGFR-gátló cetuximab, valamint panitumumab hatáso- sabbak volnának a VEGF-gátló bevacizumabhoz képest. A 2016. évi ESMO-kongresszuson a vonatkozó kontrollált klinikai vizsgálatok vezetôinek bevonásával vitaszekciót szerveztek. Az előadók a témakörben végzett hat legfontosabbnak ítélt klinikai vizsgálat metaanalízisére hivatkoztak [10], és bár óvatosan fogalmaztak, az EGFR-gátló kezelések elsőként való választását vetették fel a bal oldali RAS és BRAF vad daganatok esetében. Ugyan az időben párhuzamosan megjelent ESMO-ajánlás [11] nem említ preferenciát a kétféle célzott kezelés között, Magyarországon elkezdett gyakorlattá válni az EGFR-gátló kezelések első vonalbeli választása.

A közlemény célja az ESMO-kongresszuson bemutatott metaanalízis kritikus elemzése a beválasztott klinikai vizsgálatok rövid áttekintése alapján. (Ugyanakkor nem célunk az ESMO-ajánlások részletes ismertetése, hiszen ezek egyrészt a honlapon elérhetők [11], másrészt az újabb eredmények függvényében várhatóan változni is fognak.)

\section{A bal-jobb colondiszkusszió három vetülete}

A bal-jobb colondiszkusszió nem egy, hanem három, egymással csak részben összefüggó összevetést foglal magába. Az első a két colonfélben előforduló daganatok prognózisának az összehasonlítása. A második a célzott kezelések hozzáadott értékének meghatározása a kemoterápiához képest. A harmadik a különböző támadáspontú célzott kezelések egymással történő összehasonlítása. A kérdéskör tárgyalásakor a három összevetés egybemosása jelentôs torzításokhoz vezet.

A jobb és bal colonfél közötti határ az arteria mesenterica superior és inferior érellátási területek közötti határnak felel meg, ami a flexura lienalistól oralisan, egyéntől függően valahol a colon transversumon helyezkedik el. Magassága anatómiai variabilitást mutat, és kolonoszkópos vizsgálat során pontosan nem azonosítható be. A két colonfél daganatai fejlődéstani, genetikai, epidemiológiai, tünettani és prognosztikai szempontból is különböznek egymástól (1. táblázat). Az eltérések azonban csak statisztikai jellegúek, vagyis a gyakoriságban mutatkoznak meg, és nem állapítható meg elvágólagos határ közöttük [10].

A célzott kezelések hatásosságát randomizált vizsgálatok validálták. A kemoterápiához történő hozzáadásuk értékének elemzése nem tartozik jelen közlemény célkitűzései közé. Az alapvizsgálatok közül hármat beválasztottak az ESMO-kongresszuson bemutatott metaanalízisbe (2. táblázat). A célzott biológiai kezelések hatásosságának egymással történő összemérése klinikai szempontból fontos kérdés. A továbbiakban ennek a kérdésnek az elemzésével foglalkozunk.

\section{A metaanalizis módszertani kritikája}

A metaanalízis legjelentősebb módszertani korlátjának tartjuk, hogy a hat beválasztott vizsgálat közül háromnál 
1. táblázat

Jobb és bal colonfél közötti különbségek

\begin{tabular}{lll}
\hline & Jobb & Bal \\
\hline Vérellátás & $\begin{array}{l}\text { Arteria mesenterica } \\
\text { superior }\end{array}$ & $\begin{array}{l}\text { Arteria mesenterica } \\
\text { inferior }\end{array}$ \\
\hline Fejlödéstan & Középbél & Utóbél \\
\hline Genetika & MSI, mBRAF & - \\
\hline Praecancerosus laesio & Serrated adenoma & $\begin{array}{l}\text { Adenomatosus } \\
\text { polypus }\end{array}$ \\
\hline Epidemiológia & $20 \%$ & $80 \%$ \\
\hline Tünettan & Okkult vérzés & Passzázszavar \\
\hline Prognózis & Rosszabb & Jobb \\
\hline
\end{tabular}

mBRAF $=$ BRAF gén mutációja; MSI = mikroszatellita-instabilitás

2. táblázat |Az ESMO 2016 kongresszuson bemutatott metaanalízisbe be vont hat vizsgálat legfontosabb adatai a bal colonfélre vonatkozólag

\begin{tabular}{|c|c|c|c|c|c|}
\hline Study & Protokoll & Vonal & Esetszám & OS & PFS \\
\hline \multirow[t]{2}{*}{ Prime } & $\begin{array}{l}\text { Panitumumab + } \\
\text { FOLFOX }\end{array}$ & \multirow{2}{*}{ 1. vonal } & 169 & $30,3^{*}$ & 12,9 * \\
\hline & FOLFOX & & 159 & 23,6 & 9,2 \\
\hline \multirow[t]{2}{*}{ Peak } & $\begin{array}{l}\text { Panitumumab + } \\
\text { OLFOX }\end{array}$ & \multirow{2}{*}{ 1. vonal } & 53 & 43,4 & 14,6 \\
\hline & $\begin{array}{l}\text { Bevacizumab + } \\
\text { FOLFOX }\end{array}$ & & 54 & 32,0 & 11,5 \\
\hline \multirow[t]{2}{*}{20050181} & $\begin{array}{l}\text { Panitumumab + } \\
\text { FOLFIRI }\end{array}$ & \multirow{2}{*}{ 2. vonal } & 150 & 20,1 & 8,0 \\
\hline & FOLFIRI & & 148 & 16,6 & 5,8 \\
\hline \multirow[t]{2}{*}{ FIRE3 } & $\begin{array}{l}\text { Cetuximab + } \\
\text { FOLFIRI }\end{array}$ & \multirow{2}{*}{ 1. vonal } & 157 & $38,3^{*}$ & 10,3 \\
\hline & $\begin{array}{l}\text { Bevacizumab + } \\
\text { FOLFIRI }\end{array}$ & & 149 & 28,0 & 10,3 \\
\hline \multirow[t]{2}{*}{ Crystal } & $\begin{array}{l}\text { Cetuximab + } \\
\text { FOLFIRI }\end{array}$ & \multirow[t]{2}{*}{ 1. vonal } & 175 & $28,7^{*}$ & 12,0 * \\
\hline & FOLFIRI & & 189 & 21,7 & 8,9 \\
\hline \multirow[t]{2}{*}{ CALGB } & Cetuximab + CT & \multirow{2}{*}{$\begin{array}{l}1 .+2 . \\
\text { vonal }\end{array}$} & 173 & $39,3 *$ & 12,7 \\
\hline & $\begin{array}{l}\text { Bevacizumab + } \\
\text { CT }\end{array}$ & & 152 & 32,6 & 11,2 \\
\hline
\end{tabular}

*Statisztikailag szignifikáns eltérés a kontrollkarhoz képest.

$\mathrm{CT}=$ kemoterápia FOLFOX-, illetve FOLFIRI-protokoll szerint; OS = overal survival; $\mathrm{PFS}=$ progression - free survival

az EGFR-gátló kezelések kontrollcsoportját nem VEGFgátló kezelés, hanem kemoterápia képezte (3. táblázat). A különböző támadáspontú célzott kezelések első vonalbeli alkalmazásának összehasonlítására ilyen torzítás mellett következtetést levonni nem lehetséges.

A metaanalízis másik jelentős korlátja, hogy eltérő kezelési sémákban vizsgálta a készítményeket, négy első vonalbeli vizsgálat mellé egy másodvonalbeli és egy elsőmásod vonalbeli keresztezett vizsgálatot társított. A legélesebb koncepciót érintő eltérést a FIRE3 és a CALGB vizsgálat között az irodalom korábban részletesen elemezte $[9,12,13]$.
3. táblázat |Az ESMO 2016 kongresszuson bemutatott metaanalízis kritikája

\begin{tabular}{l}
\hline A metaanalízis hiányosságai \\
\hline CT és célzott kezeléses kontrollok keverése. \\
\hline Csak az l. vonal kontrollált (CALGB kivételével). \\
\hline Csak retrospektív analízis. \\
\hline Csak a résztvevók $37,6 \%$-át vonták be. \\
\hline Vizsgálatok között azonos karon magas OS-eltérés.
\end{tabular}

Vizsgálatok között azonos karon magas OS-eltérés.

$\mathrm{CT}=$ kemoterápia FOLFOX-, illetve FOLFIRI-protokoll szerint; OS = overall survival

A FIRE3 [7] első vonalban hasonlította össze a cetuximab + FOLFIRI kombinációt a bevacizumab + FOLFIRI kombinációval. Szignifikáns teljes túlélési előnyt talált a cetuximab javára anélkül, hogy a progressziómentes túlélésben eltérést mutatott volna ki. A CALGB [13] kétszeresen keresztezett felépítésben első és második vonalban hasonlította össze a cetuximab + FOLFOX/FOLFIRI kombinációt a bevacizumab + FOLFIRI/FOLFOX kombinációval. Sem a teljes, sem a progressziómentes túlélésben nem talált különbséget a két kar között. A CALGB vizsgálat előnyei: a kontrolláltság kiterjesztése két vonalon át, illetve a progreszsziómentes és a teljes túlélési idő közötti koherencia. A két vizsgálat retrospektív analízisbe beválasztott esetszáma nagyságrendileg hasonló volt. Mindkét vizsgálat hiányossága, hogy a vizsgálat utáni kezelésekról nem közöltek elegendő információt. A FIRE3 vizsgálatnak a CALGB vizsgálathoz képest módszertani előnyét nem találtuk.

Megjegyezzük, hogy a korábbi, vastagbéldaganatokra vonatkozó klinikai vizsgálatokban szisztematikusan a progressziómentes túlélésben észleltek először előnyt a teljes túlélésben tapasztalt előnyhöz képest [1-8]. Az olyan adatok, amelyek a progressziómentes túlélésben megnyilvánuló eltérés nélkül teljes túlélési előnyt mutatnak, szokatlanok. Ezenkívül általánosságban a progreszsziómentes túlélés annál kevésbé értékelhető a teljes túlélés surrogate markereként, minél több kezelési vonal követi a vizsgálati időtartamot.

A bal oldali colontumorokra vonatkozólag a FIRE3 vizsgálat jelentős túlélési előnyt mutatott első vonalbeli alkalmazás esetén a cetuximab javára. A CALGB vizsgálat ugyan szintén jelzett minimális statisztikailag szignifikáns $(\mathrm{p}<0,04)$ előnyt, de a Kaplan-Meyer-görbék kétszeri kereszteződése miatt ez csak korlátozottan vehető figyelembe.

A metaanalízis szerzői maguk is beismerik [10], hogy a csupán retrospektív analízis statisztikai következtetéseket nem enged meg. Ezért ennek részletes elemzésétől eltekintünk. Kiemeljük azonban, hogy a retrospektív elemzésbe a vizsgálatokban részt vevő teljes populációnak csupán 37,6\%-át vették be, ami további módszertani korlátot jelent. (A kizárások fó okainak az ismeretlen RAS-státuszt és a nem pontosan meghatározott lokalizá- 
ciót említik.) Így az alacsonyabb előfordulási arány alapján a jobb oldali daganatok száma különösen kevés, a kezelési szándék miatt erösebben célba vett bal oldali daganatok esetszáma elfogadható volna, de a szelekciós hiba lehetôsége ebben az esetben sem zárható ki.

A különböző vizsgálatok azonos kezelési karjai között a túlélési időtartamok jelentős eltérést mutatnak. Ugyan különböző vizsgálatok direkt összehasonlítása módszertanilag szintén nem megengedett, de fordítva, a magas eltérések a metaanalízis értékét rontják. Végül megjegyzésre érdemes, hogy a metaanalízisből egyes vizsgálatok (például: COIN, Nordic) nem kerültek be.

\section{A metaanalízis eredményei}

Az adatok kritikus olvasata alapján a metaanalízis a következő eredményekre enged következtetni:

1. A vizsgálatok egybehangzóan megerôsítik, hogy a jobb oldali vastagbéldaganatok prognózisa a bal oldali daganatokhoz képest rosszabb.

2. Jelenleg nem áll rendelkezésünkre elegendő adat az első vonalbeli célzott kezelés megválasztására RAS és BRAF vad áttétes bal oldali vastagbéldaganat terápiájában.

3. Több vizsgálat retrospektív analízise arra utal, hogy a jobb oldali vastagbéldaganatok kezelésében az EGFRgátló kezelésnek a kemoterápiához képest hozzáadott előnye jelenleg nem mutatható ki.

\section{Megbeszélés}

A vastagbéldaganatok kezelésében alkalmazott kemoterápiás és célzott terápiás gyógyszerek hatásosságát kontrollált klinikai vizsgálatokkal igazolták, ám a célzott kezelések alkalmazási sorrendjére jelenleg nincs elegendő evidencia. A rendelkezésre álló gyógyszerek magas száma miatt nehezen elképzelhető, hogy az optimális szekvencia meghatározására valaha megfelelő klinikai vizsgálatot tervezzenek. Ezért a gyakorlati döntéshozatalban az onkológusok egyéb szempontokat is figyelembe vesznek: szakmai ajánlásokat (például: ESMO guideline), klinikai megfigyeléseket (például: bevacizumab through multiple lines, hepaticus és pulmonalis metastasectomia), a mellékhatások csökkentését (például: oxaliplatindózislimitálás, drug holiday) és piaci szempontokat [9].

Amennyiben RAS és BRAF vad inoperábilis metasztatikus colorectalis tumoros beteg első vonalban FOLFIRI-bevacizumab kombinációt kap, második vonalban „through multiple lines” elv alapján FOLFOX-bevacizumab, harmadik vonalban szóló EGFR-gátló kezelést, és amennyiben általános állapota lehetővé teszi, negyedik vonalban esetleg regorafenib vagy TAS-102 adható. (Ha a beteg a tablettás kezelést választja az 5FU-infúzió helyett, Xeloda adásával XELIRI-, illetve XELOX-protokoll megfelelő alternatíva lehet a bevacizumab mellett.)

Amennyiben a beteg első vonalban EGFR-gátló szert kap a FOLFIRI-kemoterápia mellé, akkor progresszió esetén második vonalban FOLFOX-bevacizumab és harmadik vonalban regorafenib vagy TAS-102 adása a kézenfekvő folytatási lehetőség.

Egyik stratégia sem tekinthető elsőrendünek, de a rendelkezésre álló evidenciák alapján nem is vethető el alkalmazásuk. Ezeken kívül más kezelési szekvenciák is szóba jöhetnek. A tervek szerint számítani lehet a jobb és bal colonfél különbségeit és a szekvencia kérdését is lehetőség szerint figyelembe vevő prospektív vizsgálatokra. Csak az ilyen vizsgálatok eredményének ismeretében lehet majd egyértelmúen állást foglalni az irreszekábilis metasztatikus vastagbéldaganatok első vonalbeli célzott kezelésének optimális megválasztását illetően.

\section{Következtetés}

A jobb oldali vastagbéldaganatok prognózisa a bal oldali daganatokhoz képest rosszabb. Jelenleg nincs elegendő tudományos evidencia bal oldali metasztatikus colorectalis carcinoma első vonalbeli kezelésének megválasztására. Szintén nincs elegendő evidencia jobb oldali metasztatikus colorectalis carcinoma esetén az EGFR-gátló kezelések alkalmazására.

Anyagi támogatás: A közlemény anyagi támogatásban nem részesült.

Szerzői munkamegosztás: K. T.: A közlemény összeállítása. S. I., P. T.: A közlemény véleményezése és javítása. A végleges változatot mindegyik szerző elolvasta és jóváhagyta.

Érdekeltségek: A szerzőknek a közlemény megjelentetésével kapcsolatban nincsenek érdekeltségeik.

\section{Irodalom}

[1] Buroker, T. R., O'Connell, M. J., Wieand, H. S., et al.: Randomized comparison of two schedules of fluorouracil and leucovorin in the treatment of advanced colorectal cancer. J. Clin. Oncol., 1994, 12(1), 14-20.

[2] De Gramont, A., Bosset, J. F., Milan, C., et al.: Randomized trial comparing monthly low-dose leucovorin and fluorouracil bolus with bimonthly high-dose leucovorin and fluorouracil bolus plus continuous infusion for advanced colorectal cancer: a French intergroup study. J. Clin. Oncol., 1997, 15(2), 808-815.

[3] De Gramont, A., Figer, A., Seymour, M., et al.: Leucovorin and fluorouracil with or without oxaliplatin as first-line treatment in advanced colorectal cancer. J. Clin. Oncol., 2000, 18(16), 29382947.

[4] Douillard, J. Y., Cunningham, D., Roth, A. D., et al.: Irinotecan combined with fluorouracil compared with fluorouracil alone as first-line treatment for metastatic colorectal cancer: a multicentre randomised trial. Lancet, 2000, 355(9209), 1041-1047.

[5] Tournigand, C., André, T., Achille, E., et al.: FOLFIRI followed by FOLFOX6 or the reverse sequence in advanced colorectal cancer: a randomized GERCOR study. J. Clin. Oncol., 2004, $22(2), 229-237$ 
[6] Hurwitz, H., Fehrenbacher, L., Novotny, W., et al.: Bevacizumab plus irinotecan, fluorouracil, and leucovorin for metastatic colorectal cancer. N. Engl. J. Med., 2004, 350(23), 2335-2342.

[7] Heinemann, V., von Weikersthal, L. F., Decker, T., et al.: FOLFIRI plus cetuximab versus FOLFIRI plus bevacizumab as first-line treatment for patients with metastatic colorectal cancer (FIRE-3): a randomised, open-label, phase 3 trial. Lancet Oncol., 2014, 15(10), 1065-1075.

[8] Peeters, M., Oliner, K. S., Price, T. J., et al.: Analysis of KRAS/ NRAS Mutations in a Phase III Study of Panitumumab with FOLFIRI Compared with FOLFIRI Alone as Second-line Treatment for Metastatic Colorectal Cancer. Clin. Cancer Res., 2015, 21(24), 5469-5479.

[9] O’Neil, B. H., Venook, A. P.: Trying to understand differing results of FIRE-3 and 80405: Does the first treatment matter more than others? J. Clin. Oncol., 2015, 33(32), 3686-3688.
[10] Ciardiello, F. (chair).: Right or left metastatic colon cancer: Will the side change your treatment? ESMO 2016 Congress, 7-11 October 2016, Copenhagen, Denmark.

[11] ESMO Clinical Practice Guidelines. Available from: http:// www.esmo.org/Guidelines/Gastrointestinal-Cancers/Management-of-Patients-with-Metastatic-Colorectal-Cancer (2016.12. 31.)

[12] Heinemann, V., Stintzing, S.: FOLFIRI with cetuximab or bevacizumab: FIRE-3-authors' reply. Lancet Oncol., 2014, 15(13), e583-e584.

[13] Venook, A. P.: Bevacizumab vs. EGFR antibodies in metastatic colorectal cancer. Clin. Advances Hematol. Oncol., 2015, 13(2), 90-92.

(Kullmann Tamás dr., Györ, Vasvári Pál u. 2-4., 9024 e-mail: kullmanndoki@hotmail.com)

\section{FELHÍVÁS}

\section{a „Kedves Nővér” Alapítvány a II. sz. Belgyógyászati Klinika nővérei és a Klinika támogatására}

A Semmelweis Egyetem II. sz. Belgyógyászati Klinikája meghatározó szerepet játszik mind a fekvő- mind járóbeteg-ellátásban, az oktatásban és a tudományos kutatásban is.

Fő betegellátási profiljaink az endokrinológia, a diabetológia, a gasztroenterológia, a hepatológia, valamint az immunológia, a kardiológia és az onkológia. E profilokban a fekvőbetegek kezelésében és a járóbetegek ellátására szakosodott ambulanciák révén veszünk részt.

Klinikánk „Kedves Nővér” Alapítványa (teljes nevén „Kedves Nővér” Alapítvány a II. sz. Belgyógyászati Klinika nővérei és a Klinika támogatására) jelentősen hozzájárul a klinika fejlődéséhez, a klinikán dolgozó nővérek munkakörülményeinek javításához. Az alapitvány révén beszerezhető eszközök és kivitelezhető fejlesztések nagyban elősegítik a II. Belgyógyászati Klinika müködését.

\section{A tervezett föbb fejlesztések és beszerzések:}

- Gasztroenterológiai osztályunk és ambulanciánk fejlesztése (pl. endoscopos UH beszerzése).

- Endokrinológiai osztályunk fejlesztése (ennek keretében a súlyosan elhízott betegek testtömegének mérését lehetővé tévő digitális mérlegek beszerzése).

- Korszerű Kardiológiai őrző építészeti-gépészeti kialakítása, és eszközbeszerzések.

- Transzplantált betegek utógondozására alkalmas osztály kialakitása, és az ehhez szükséges eszközök biztosítása.

- Higiéniai berendezések (pl. mosogatógép) beszerzése.

Mindezen fejlesztési tervek betegeink és dolgozóink körülményeit is nagyban javítanánk.

Nagyon megköszönnénk, ha adójuk 1\%-ának a felajánlásával vagy közvetlen pénzbeli adománnyal támogatni tudnák a „Kedves Nővér" Alapítványon keresztül a II. sz. Belgyógyászati Klinikát abban, hogy a fent említett terveink mielőbb megvalósulhassanak.

A Kedves Nővér Alapítvány főbb adatai:

Adószám: 19622330-1-42

Bankszámlaszám: K\&H Bank 10200823-22217826-00000000

Cím: 1088 Budapest, Szentkirályi u. 46.

\author{
Dr. Lengyel Gabriella \\ egyetemi docens
}

a Kedves Nővér Alapítvány kuratóriumának tagja

\author{
Dr. Igaz Péter \\ klinikaigazgató és \\ a Kedves Nővér Alapítvány kuratóriumának elnöke
}

